\title{
ANALISA HUJAN LIMPASAN DI SUB DAS GONGSENG BOJONEGORO MENGGUNAKAN JARINGAN SARAF TIRUAN
}

\author{
Poetri Mustika Chandy $^{1)}$, Ery Suhartanto ${ }^{1)}$, Sri Wahyuni ${ }^{1, *)}$ \\ ${ }^{1)}$ Jurusan Teknik Pengairan Universitas Brawijaya \\ Jl. Mayjend, Hartono no 167, Malang, 65145, Indonesia \\ ${ }^{*}$ Email: yuniteknik@ub.ac.id
}

\begin{abstract}
Discharge data or surface runoff data in a watershed need to be known to analyze water availability in the watershed. However, not all watersheds have measurements. Therefore, it needs analysis to transform rainfall data into discharge. This study aims to transform rainfall data into discharge using the Artificial Neural Network (ANN) method. The ANN model uses the Matlab R2014b application program. The research location is in the Gongseng Sub-watershed in Bojonegoro Regency, East Java. The data used are the number of rainy days, rainfall, runoff coefficients, and discharge data (as calibration). The data used are 12 years (2006-2017). Analysis was carried out on three (3) processes, namely calibration, verification and validation. The calculation results of the best calibration process when using 6 years of data (2006-2011) with epoch 2000 that produces an NSE value of 0.69 and an $R$ value of 0.85 . As for the verification and validation process when using 1 year of data (2017) with epoch 1000, it produces an NSE value of 0.79 (good) and an $R$ value of 0.92 (a very strong relationship). From these results it was concluded that this method is appropriate to be applied at this research location, and also applied to other locations that have similarity condition with this watershed characteristics.
\end{abstract}

Kata kunci : surface runoff, artificial neural network, calibration, verification, validation

\section{PENDAHULUAN}

Hujan yang turun pada suatu Daerah Aliran Sungai sebagian terjadi infiltrasi dan yang lainnya menjadi limpasan permukaan. Limpasan terjadi pada curah hujan yang melebihi kapasitas infiltrasi. Pada beberapa daerah tertentu tidak terdapat alat pengukur debit, seperti halnya pada lokasi penelitian ini. Oleh karena itu dibutuhkan pemodelan hujan limpasan yang dapat dijadikan alat untuk mengontrol dan mengevaluasi aliran pada suatu kawasan atau DAS.
Masalah yang ada di daerah lokasi penelitian harapannya teratasi dengan memanfaatkan teknologi software komputer dengan menggunakan Jaringan Saraf Tiruan (JST) atau yang disebut Artificial Neural Network (ANN). JST ini mempunyai banyak kemampuan untuk mendapatkan informasi dan memecahkan suatu masalah, dari data yang rumit atau tidak tepat.

Peneliti terdahulu yang mengenai hujan limpasan menggunakan JST 
diantaranya yaitu (Riad dkk, 2003; Widyastuti, 2016; Hadihardaja dan Sutikno, 2005; Ardana 2013). Pada penelitian Riad dkk (2003) menyebutkan bahwa pada terdapat hubungan antara model hujan limpasan dengan JST, yang dapat membantu dalam bidang perencanaan dan managemen sumber daya air. Penelitian ini membandingkan 2 metode yaitu model JST dan model MLR, dengan hasil metode JST lebih bagus yaitu dengan nilai $R^{2}=0,948$ pada training dan 0,917 pada testing.

Penelitian yang dilakukan oleh Widyastuti (2006) menggunakan data berupa curah hujan, evapotranspirasi, koefisien aliran, dan debit stasiun AWLR. Penelitian tersebut menyatakan bahwa mengkaji keterkaitan besarnya curah hujan harian yang tersedia, faktor klimatologi terkait evapotranspirasi terhadap debit limpasan yang terjadi, dimana diperoleh nilai MSE 0,0393, NSE $\mathrm{R}^{2}>0,999$ dan $\mathrm{R}$ dalam $\mathrm{R}^{2}>0,999$.

Penelitian Hadihardaja dan Sutikno (2005) menggunakan input hujan dan output limpasan model, diperoleh koefisien korelasi tertinggi 0,813 dengan kesimpulan dapat diterapkan dalam pemodelan walaupun hasilnya masih ada penyimpangan. Sedangkan pada Ardana (2013) menggunakan data iklim (kecepatan angin, kelembaban relatif, kelembaban maksimum dan lama penyinaran) serta data hidrologi yaitu data hujan, data debit dan evapotranspirasi. Dari Hasil penelitian, model JST metode backpropagation dengan pembelajaran Gradien Descent dan Adaptive
Learning Rate memberikan hasil relatif baik pada proses training dan testing.

$$
\text { Penelitian tentang hujan }
$$

limpasan dengan metode Nreca dan Mock, Wahyuni (2014). Lokasi penelitian tersebut dekat dengan lokasi penelitian ini. Dimana dari dua metode tersebut metode Mock lebih baik, dengan hasil RMSE $=0,109 ; \mathrm{ME}=$ 0,014; dan $\mathbf{R}^{2}=0,758$ pada Kalibrasi. Pada uji validasi diperoleh RMSE = $0,126 \mathrm{ME}=0,051 ;$ dan $\mathbf{R}^{2}=0,604$.

Rumusan masalah pada penelitian ini adalah bagaimanakah hasil kalibrasi, verifikasi dan validasi debit model jaringan saraf tiruan dengan debit pengamatan, menggunakan metode uji NSE, R, KR dan RMSE.

\section{METODE PENELITIAN}

Penelitian ini memiliki tiga tahap utama, yaitu tahapan pertama berupa pengolahan data input yaitu data curah hujan, data debit, serta koefisien aliran. Selanjutnya tahap pengolahan data dengan pemodelan Jaringan Saraf Tiruan menggunakan software Matlab R2014b, dan tahap terakhir adalah hasil dari data pemodelan akan dihitung nilai penyimpangannya.

1. Pengolahan data input dilakukan analisa kualitas data hidrologi dengan uji konsistensi (uji kurva massa ganda untuk data hujan dan uji RAPS untuk data debit), uji ketidakadaan trend, uji stasioner, dan uji persistensi. Selanjutnya menghitung hujan rerata daerah poligon thiessen dan nilai koefisien aliran. 
2. Tahap pengolahan data dengan JST menggunakan Matlab. Pembagian data antara lain data input, data sampel dan data target. Komposisi data pembagian dibagi menjadi beberapa pengerjaan antara lain:
a. $6-6$ tahun
b. 7 - 5 tahun
c. 8 - 4 tahun
d. $9-3$ tahun
e. 10 - 2 tahun, dan
f. $11-1$ tahun.

Sebagai contoh pada pembagian data menjadi 6-6 tahun artinya 6 tahun pertama (2006-2011) sebagai perhitungan debit untuk tahap kalibrasi, dan 6 tahun berikutnya (2012-2017) sebagai tahap validasi.

Setelah itu melakukan perancangan model arsitektur jaringan dengan metode backpropagation, dan dilanjutkan pelatihan data, validasi data, pengujian data serta melakukan simulasi model data sampel.

3. Tahap uji kalibrasi, verifikasi dan validasi dengan 4 metode uji yaitu Nash-Sutcliffe Efficiency (NSE), koefisien korelasi (R), kesalahan relatif (KR) dan Root Mean Square Error (RMSE).

Diagram alir penelitian dapat dilihat seperti pada gambar 1 di bawah.

\section{HASIL DAN PEMBAHASAN}

Data yang dibutuhkan antara lain data curah hujan, data debit, jumlah hari hujan dan nilai koefisien aliran. Pengumpulan data curah hujan dan data debit masing-masing selama 12 tahun (2006 - 2017) diperoleh dari UPT PSDA di Bojonegoro, Jawa
Timur. Adapun stasiun yang dimaksud adalah Pos Stasiun Hujan Tretes, Gangseng, Sugihan dan Pos Duga Air Gangseng.

Uji konsistensi data yang digunakan pada penelitian ini adalah kurva massa ganda untuk data curah hujan. Sedangkan data debit menggunakan uji RAPS.

Uji kurva massa ganda dengan membandingkan akumulasi curah hujan tahunan dengan akumulasi curah hujan rerata stasiun hujan di sekitarnya sebagai stasiun pembanding. Uji ini dilakukan untuk melihat apakah terdapat penyimpangan dari data yang dipakai. Pengujian dikatakan konsisten apabila diperoleh besar kemiringan sudut garis trend pada grafik sebesar $\alpha=45$.

Perhitungan besar sudut $\alpha$ kurva massa ganda Stasiun Tretes :

$$
\begin{aligned}
y & =b x \\
b & =\text { kemiringan garis } b(S) \\
y & =0,7838 x \\
S & =0,7838
\end{aligned}
$$

Sehingga, nilai $\alpha=\arctan \mathrm{S}$

$$
\begin{aligned}
\alpha & =\arctan (0,7838) \\
& =38,09^{\circ}
\end{aligned}
$$

Nilai a Stasiun Tretes adalah $38,09^{\circ}$ yang berarti tidak konsisten, maka pada perlu dilakukan perhitungan faktor koreksi $\left(\mathrm{F}_{\mathrm{K}}\right)$ dengan tujuan memperbaiki data sehingga nilai $\alpha$ sesuai dengan batas yang diijinkan. Berikut contoh perhitungan nilai Fk:

$\mathrm{Fk}=\frac{S_{\text {koreks } i}}{S_{1}}=\frac{1}{0,7836}=1,276$

Setelah didapatkan nilai faktor koreksi $\left(\mathrm{F}_{\mathrm{K}}\right)$, maka curah hujan di 
Stasiun Tretes dikalikan dengan $\left(\mathrm{F}_{\mathrm{K}}\right)$ yaitu 1,276 sehingga data menjadi terkoreksi. Perhitungan besar sudut $\alpha$ kurva massa ganda Stasiun Tretes setelah dikoreksi :

$$
\begin{aligned}
\mathrm{y} & =1,0003 \mathrm{x} \\
\mathrm{S} & =1,0003
\end{aligned}
$$

Sehingga, nilai $\alpha=\arctan \mathrm{S}$

$\alpha=\arctan (1,0003)$

$$
=45,04^{\circ}
$$

Nilai $\alpha$ Stasiun Gangseng setelah menggunakan data dikoreksi adalah $45,04^{\circ}$ maka telah konsisten.

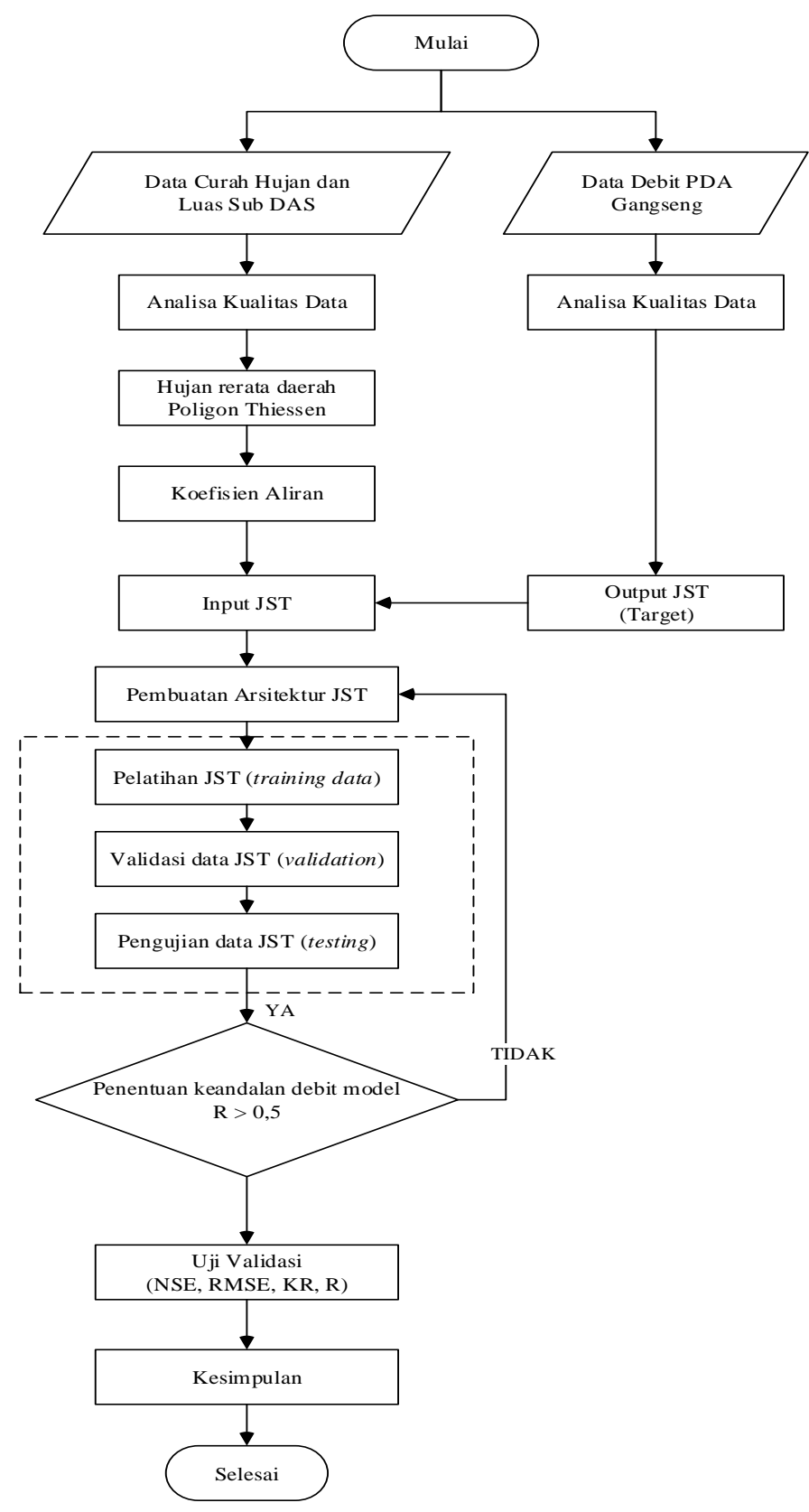

Gambar 1. Diagram Alir Penelitian 


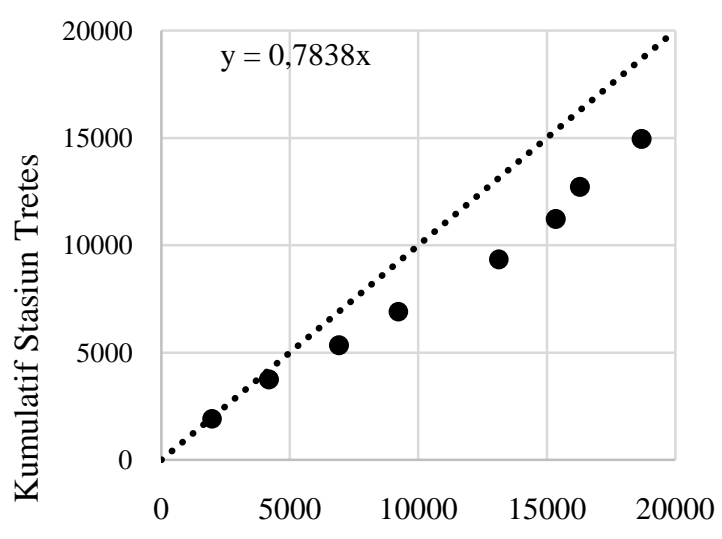

Kumulatif Rerata Stasiun Pembanding

Gambar 2. Grafik Uji Konsistensi Stasiun Tretes

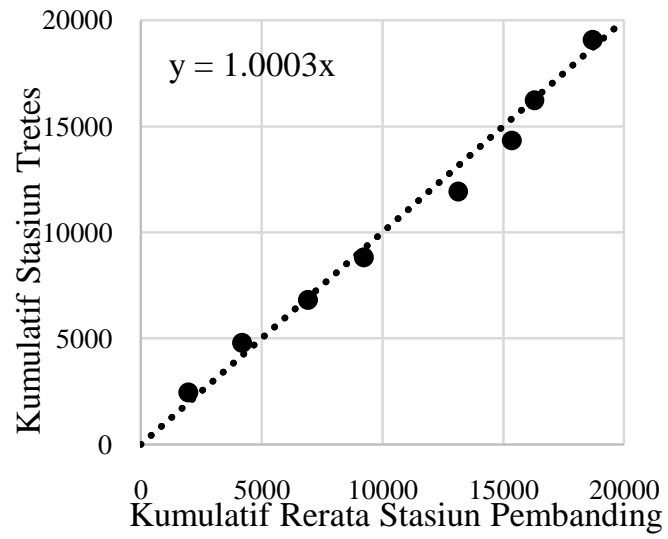

Gambar 3. Grafik Uji Konsistensi Stasiun Tretes Terkoreksi

Pengujian data debit pos duga air ini menggunakan metode RAPS (Rescaled Adjusted Partial Sums). Pemilihan metode RAPS ini dikarenakan data debit adalah data tunggal. Hasil uji konsistensi dapat dilihat pada Tabel 2. Selanjutnya adalah uji ketidakaadan trend. Tujuan pengujian ini untuk mengetahui adanya trend pada data atau tidak. Pengujian ini dilakukan dengan beberapa metode yaitu uji spearman, uji mann whitney dan uji tanda cox dan struat (Soewarno, 1995, pp.85-86). Hasil uji ketidakadaan trend dapat dilihat pada Tabel 3.

Tabel 2. Uji Konsistensi

\begin{tabular}{ccccc}
\hline \multirow{2}{*}{ Nama Titik } & Kurva Massa Ganda & \multicolumn{2}{c}{ RAPS } & \\
\cline { 2 - 4 } & Sudut & $\frac{Q}{\sqrt{n}}$ & $\frac{R}{\sqrt{n}}$ & Keterangan \\
\hline Tretes & 45,04 & - & - & Konsisten \\
Gangseng & 44,68 & - & - & Konsisten \\
Sugihan & 45,65 & - & - & Konsisten \\
PDA Gangseng & - & 0,33 & 1,16 & Konsisten \\
\hline
\end{tabular}


Keterangan:

$\mathrm{Q}=$ nilai statistik untuk $\mathrm{Q}$

$\mathrm{R}=$ nilai statistik untuk Range

Tabel 3. Uji Ketidakadaan Trend

\begin{tabular}{|c|c|c|c|c|}
\hline Nama Pos & $\alpha$ & Spearman & Mann Whitney & $\begin{array}{c}\text { Tanda Cox dan } \\
\text { Struat }\end{array}$ \\
\hline Tretes & \multirow{4}{*}{$5 \%$} & diterima & diterima & diterima \\
\hline Gangseng & & diterima & diterima & diterima \\
\hline Sugihan & & diterima & ditolak & ditolak \\
\hline PDA Gangseng & & ditolak & ditolak & ditolak \\
\hline Tretes & \multirow{4}{*}{$1 \%$} & diterima & diterima & diterima \\
\hline Gangseng & & diterima & diterima & diterima \\
\hline Sugihan & & diterima & diterima & diterima \\
\hline PDA Gangseng & & ditolak & diterima & diterima \\
\hline
\end{tabular}

Keterangan:

PDA $=$ Pos Duga Air

Uji Stasioner bertujuan untuk menguji kestabilan nilai varian dan rata-rata, artinya untuk mengetahui apakah kedua sampel berasal dari populasi yang sama atau tidak. Hasil uji stasioner dapat dilihat pada Tabel 4 . Selanjutnya Uji Persistensi merupakan ketidak-tergantungan dari setiap nilai dalam deret berkala dalam data hidrologi. Data tersebut dianggap data yang berasal dari sampel acak maka perlu diuji. (Soewarno, 1995, p.99). Hasil uji persistensi dengan derajat kepercayaan 5\% maupun diturunkan dengan $1 \%$ adalah ditolak atau tidak acak.

Tabel 4. Uji Stasioner

\begin{tabular}{|c|c|c|c|}
\hline Nama Pos & $\alpha$ & Uji F & Uji T \\
\hline Tretes & \multirow{4}{*}{$5 \%$} & diterima & diterima \\
\hline Gangseng & & diterima & diterima \\
\hline Sugihan & & ditolak & ditolak \\
\hline PDA Gangseng & & diterima & ditolak \\
\hline Tretes & \multirow{4}{*}{$1 \%$} & diterima & diterima \\
\hline Gangseng & & diterima & diterima \\
\hline Sugihan & & ditolak & diterima \\
\hline PDA Gangseng & & diterima & diterima \\
\hline
\end{tabular}

Keterangan:

PDA $=$ Pos Duga Air

Perhitungan hujan rerata daerah poligon thiessen untuk mendapatkan satu besaran nilai hujan suatu DAS.
Nilai ini yang akan digunakan untuk perhitungan pemodelan debit dengan JST sebagai input. Hasil poligon 


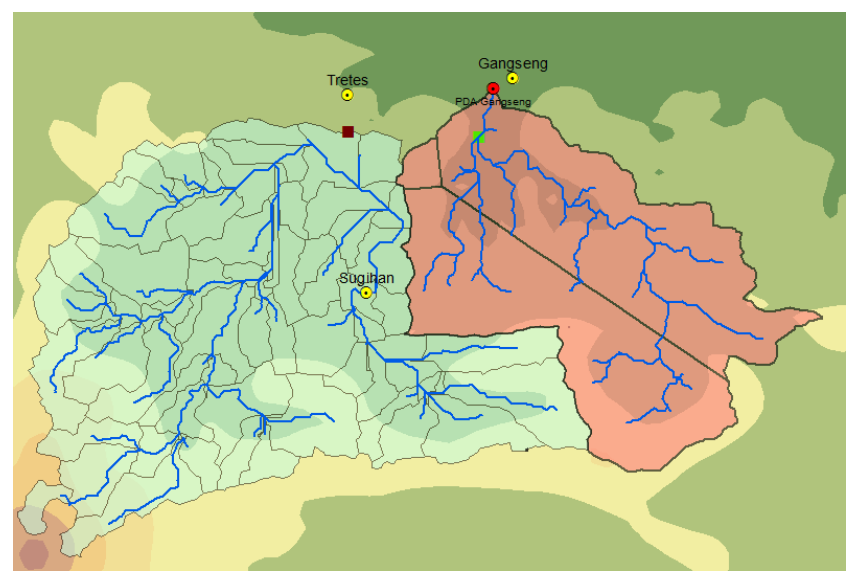

Gambar 4. Poligon Thiessen Sub DAS Gongseng

Tabel 5. Nilai Faktor Pengaruh Luas Stasiun Hujan (K)

\begin{tabular}{ccc}
\hline Stasiun Hujan & Luas $\left(\mathrm{km}^{2}\right)$ & $\mathrm{K}$ \\
\hline Tretes & 1,01 & 0,020 \\
\hline Gangseng & 26,75 & 0,517 \\
\hline Sugihan & 23,96 & 0,463 \\
\hline Jumlah & $\mathbf{5 1 , 7 2}$ & $\mathbf{1}$ \\
\hline
\end{tabular}

Setelah mendapatkan nilai hujan dari poligon thiessen, selanjutnya adalah menghitung nilai koefisien aliran berdasarkan buku Hidrologi dan Pengelolaan Daerah Aliran Sungai (Asdak, 2004, p.157).
Nilai angka $\mathrm{C}$ berada di antara 0 sampai dengan 1, angka 0 menunjukkan semua air mengalami infiltrasi, dan untuk angka 1 menunjukkan semua air hujan menjadi limpasan atau mengalir ke sungai.

Tabel 6. Nilai Koefisien aliran

\begin{tabular}{cccc}
\hline Tahun & Volume $\mathrm{CH}\left(10^{6} \mathrm{~m}^{3}\right)$ & Volume air larian $\left(10^{6} \mathrm{~m}^{3}\right)$ & Koef. air larian $(\mathrm{C})$ \\
\hline 2006 & 93 & 37 & 0,402 \\
\hline 2007 & 103 & 33 & 0,323 \\
\hline 2008 & 122 & 30 & 0,248 \\
\hline 2009 & 105 & 25 & 0,240 \\
\hline 2010 & 179 & 37 & 0,207 \\
\hline 2011 & 105 & 40 & 0,388 \\
\hline 2012 & 46 & 35 & 0,765 \\
\hline 2013 & 115 & 28 & 0,249 \\
\hline 2014 & 99 & 33 & 0,334 \\
\hline 2015 & 94 & 16 & 0,177 \\
\hline 2016 & 129 & 35 & 0,272 \\
\hline 2017 & 119 & 30 & 0,258 \\
\hline
\end{tabular}


Pengolahan Jaringan Saraf Hal ini dilakukan dengan tujuan hasil Tiruan, dengan Matlab R2014b. analisis lebih baik dan akurat. Pada Tujuan penelitian ini mempermudah penelitian merujuk pada penelitian dan mempercepat untuk mendapatkan Hasim (2008) yang menggunakan pemodelan debit yang sesuai transformasi data dengan normalisasi diharapkan pada lokasi penelitian. yaitu proses mengubah data dalam Langkah pertama adalah menyiapkan skala tertentu. Skala yang digunakan data menjadi tiga bagian yaitu input, sampel, dan target. Data input dan sampel terdiri dari data jumlah hari hujan, curah hujan dan koefisien aliran sedangkan data target adalah data debit pengamatan.

Sebelum diterapkan pada JST, data terlebih dahulu ditransformasi tanpa merubah informasi dari data asli. yaitu $(0,1)$ dimana batas bawah $(\mathrm{BB})$ adalah 0 dan batas atas (BA) adalah 1 .

$$
X^{\prime}=\frac{X-X \min }{X \max -X \min } \times(B A-B B)+B B
$$

Selanjutnya pembentukan arsitektur jaringan, pengolahan 6-6 tahun data. Dapat dilihat pada Gambar 5.

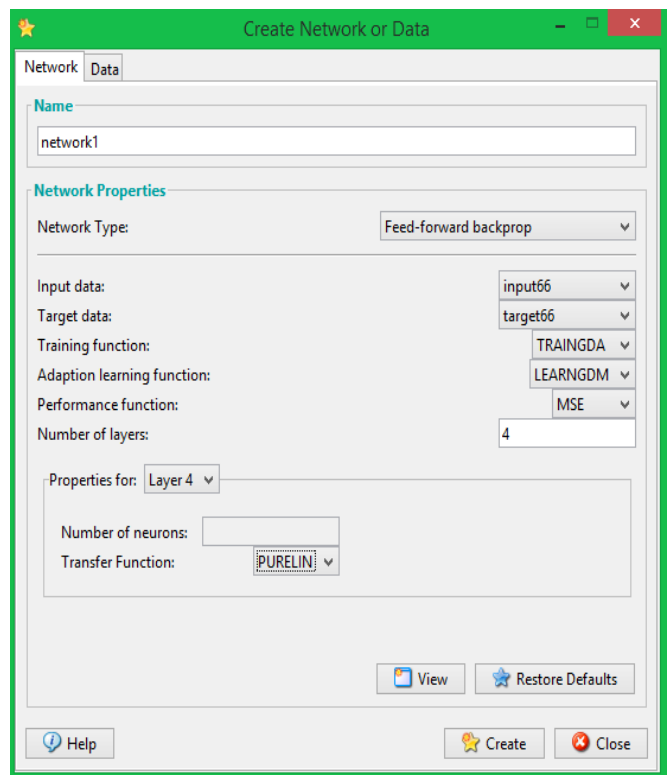

Gambar 5. Pembentukan arsitektur jaringan.

Melakukan train network berkali-kali dengan cara mengubah parameter coba-coba. Seperti Gambar 5, parameter yang dapat diubah yaitu Train function, Adaption learning function, Number of layers, Number of neurons, dan Transfer functions.

Train function adalah fungsi pelatihan yang akan digunakan.
Adaption learning function adalah fungsi pembelajaran, Number of layers adalah banyaknya layer atau lapisan yang akan digunakan. Number of neurons adalah banyaknya neuron pada masing-masing lapisan, dan Transfer functions adalah fungsi aktivasi sesuai dengan data yang digunakan. 
Hasil optimum training pada 1000, dapat dilihat pada Gambar 6. pengolahan 6-6 tahun dengan epoch

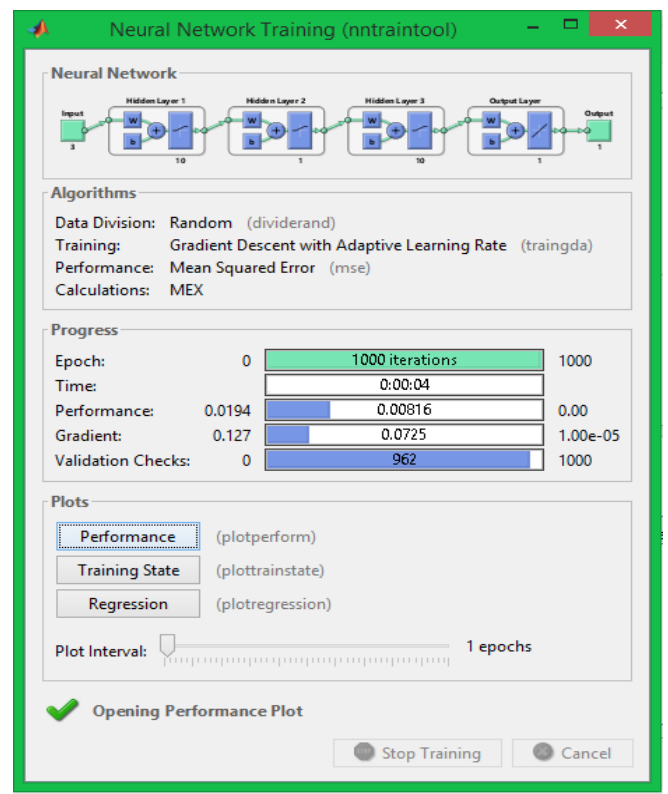

Gambar 6. Optimum Neural Network Training

Plotting optimum performance merupakan Hasil hubungan antara nilai mse (mean square error) model dan epoch. Pada pengolahan 6-6 tahun dengan epoch 1000 menunjukkan hasil best validation performance pada 0,011169. Plotting optimum performance dapat dilihat pada Gambar 7.

Gambar 8 merupakan hasil plotting optimum training state pada pengolahan 6-6 tahun data dengan epoch 1000. Terdapat 3 grafik dalam fungsi pembelajaran (training fuction) TRAINGDA ini yaitu gradient, val fail (validation checks) dan $\operatorname{lr}$ (learning rate). plotting optimum training state.

Gambar 9 merupakan hasil plotting regression optimum pada pengolahan 6-6 tahun data dengan epoch 1000. Train network berhenti ketika diperoleh nilai $\mathrm{R}$ pada plotting regresion bagus atau $\mathrm{R} \geq 0,5$ dan stabil, sehingga memperoleh hasil yang optimum.

Pada penelitian ini, hasil optimum pada parameter sebagai berikut:

- Network Type : feed-forward backup,

- Input data : input,

- Target data : target,

- Training Function : TRAINGDA,

- Adaption Function : LEARNGDM,

- Performance Function : MSE,

- Number Of Layers : 4,

- Number of Neuron : 10-1-1-1,

- Transfer Function : LOGSIG LOGSIG - LOGSIG -PURELIN

Perhitungan kalibrasi pada hasil output untuk mengetahui seberapa besar perbedaan atau selisish antara debit pengamatan dan debit model JST. Tahap Kalibrasi ini didapat nilai 
terbaik pada pembagian data 6 Tahun Kalibrasi menggunakan epoch 2000 dengan nilai NSE 0,711 dan nilai $R$ sebesar 0,844 .

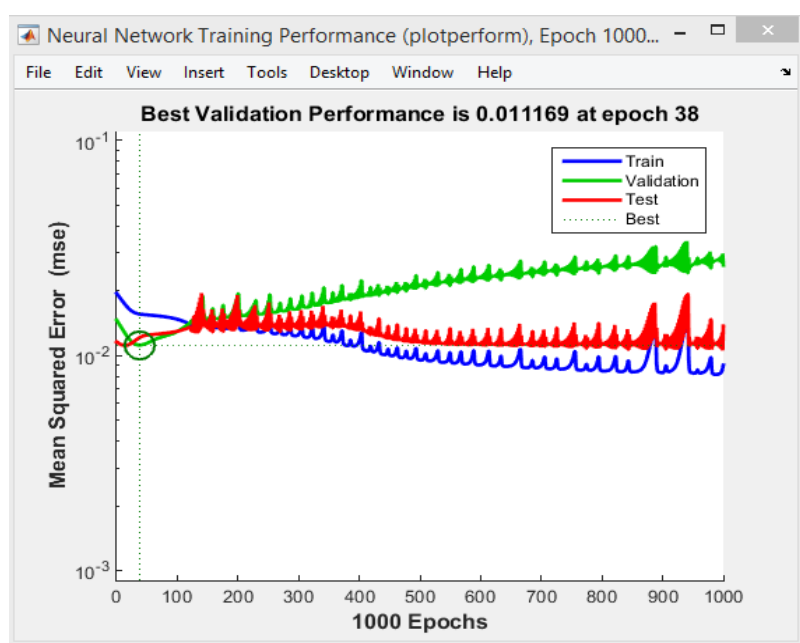

Gambar 7. Optimum Performance Trainning

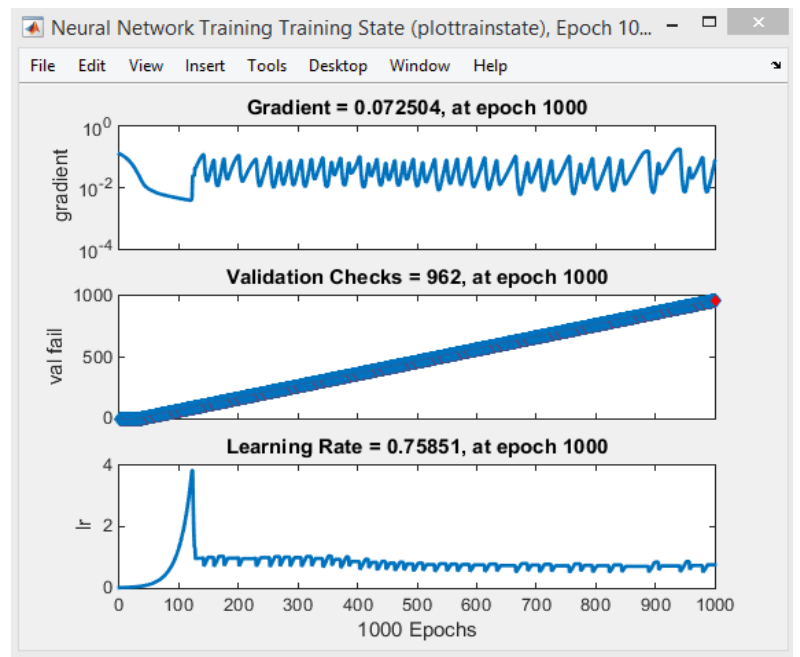

Gambar 8. Optimum Training State

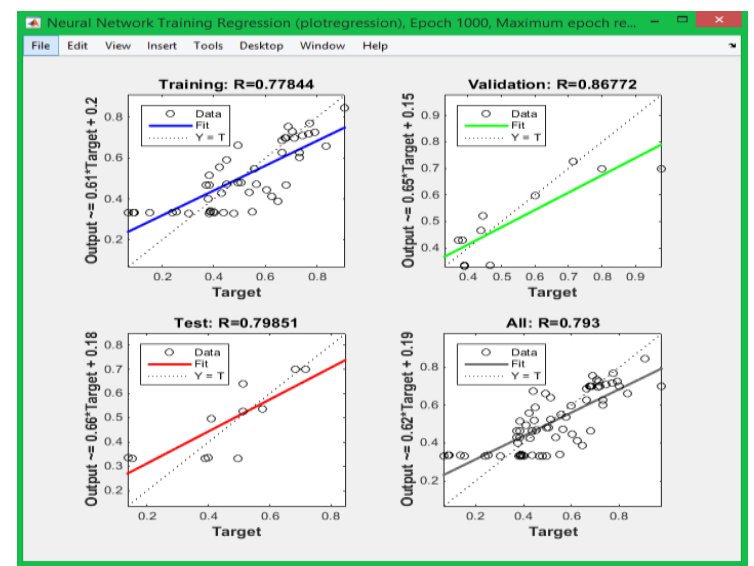

Gambar 9. Optimum Training Regression 
Tabel 7. Uji Kalibrasi

\begin{tabular}{|c|c|c|c|c|}
\hline \multicolumn{5}{|c|}{ Data 6 Tahun } \\
\hline Epoch & KR & RMSE & NSE & $\mathrm{R}$ \\
\hline 1000 & 0,296 & 7,497 & 0,628 & 0,793 \\
\hline 2000 & 0,225 & 6,608 & 0,711 & 0,844 \\
\hline 3000 & 0,250 & 7,121 & 0,665 & 0,665 \\
\hline \multicolumn{5}{|c|}{ Data 7 Tahun } \\
\hline Epoch & KR & RMSE & NSE & $\mathrm{R}$ \\
\hline 1000 & 0,261 & 7,056 & 0,652 & 0,868 \\
\hline 2000 & 0,213 & 6,930 & 0,664 & 0,865 \\
\hline 3000 & 0,284 & 7,310 & 0,626 & 0,891 \\
\hline \multicolumn{5}{|c|}{ Data 8 Tahun } \\
\hline Epoch & KR & RMSE & NSE & $\mathrm{R}$ \\
\hline 1000 & 0,297 & 8,133 & 0,613 & 0,822 \\
\hline 2000 & 0,280 & 7,558 & 0,666 & 0,857 \\
\hline 3000 & 0,389 & 8,731 & 0,554 & 0,866 \\
\hline \multicolumn{5}{|c|}{ Data 9 Tahun } \\
\hline Epoch & KR & RMSE & NSE & $\mathrm{R}$ \\
\hline 1000 & 0,323 & 8,335 & 0,573 & 0,829 \\
\hline 2000 & 0,286 & 8,123 & 0,594 & 0,818 \\
\hline 3000 & 0,389 & 8,731 & 0,554 & 0,867 \\
\hline \multicolumn{5}{|c|}{ Data 10 Tahun } \\
\hline Epoch & KR & RMSE & NSE & $\mathrm{R}$ \\
\hline 1000 & 0,534 & 8,253 & 0,673 & 0,847 \\
\hline 2000 & 0,601 & 8,638 & 0,642 & 0,827 \\
\hline 3000 & 0,412 & 7,996 & 0,693 & 0,853 \\
\hline \multicolumn{5}{|c|}{ Data 11 Tahun } \\
\hline Epoch & KR & RMSE & NSE & $\mathrm{R}$ \\
\hline 1000 & 0,348 & 8,340 & 0,656 & 0,755 \\
\hline 2000 & 0,401 & 8,060 & 0,678 & 0,762 \\
\hline 3000 & 0,551 & 8,427 & 0,648 & 0,738 \\
\hline
\end{tabular}

Verifikasi dan validasi merupakan proses evaluasi untuk menguji keakuratan terhadap model proses untuk mendapatkan gambaran tentang tingkat ketidakpastian yang dimiliki oleh suatu model. Proses ini dilakukan dengan menggunakan data di luar periode data (tahun sisa) yang digunakan dalam kalibrasi. Pada proses verifikasi melihat grafik korelasi debit pengamatan dan debit model. Dapat dilihat pada Gambar 10. Hasil validasi dapat dilihat pada Tabel 8 .

Hasil Kalibrasi debit pemodelan menggunakan JST dapat disimpulkan bahwa nilai terbaik pada pada pembagian data 6 Tahun (2006-2011) menggunakan menghasilkan nilai NSE sebesar 0,711 dan nilai $\mathrm{R}$ sebesar 0,844 . Selain itu dari semua percobaan pembagian data dari 6 tahun hingga 11 tahun Kalibrasi mendapatkan hasil yang baik karena telah memenuhi kriteria masingmasing uji dalam kalibrasi yaitu yang ditunjukan dengan semua parameter uji dengan nilai yang hampir sama.

Hasil terbaik tahap Verifikasi adalah pada pembagian data 1 tahun (2017) dengan epoch 1000 menunjukkan hasil korelasi antara debit PDA Gongseng (debit pengamatan) dan debit model JST yang mempunyai nilai koefisien korelasi (R) sebesar 0,915. Begitu pula tahap Validasi hasil terbaik debit 
pemodelan JST (pembagian data 1 tahun (2017) epoch 1000) mempunyai nilai NSE sebesar 0,794 "Baik" dan nilai R sebesar 0,915 "Sangat Kuat".

Pada umumnya semakin banyak data yang digunakan dalam tahap validasi akan menghasilkan hasil data model yang lebih baik, namun pada penelitian ini tidak. Dikarenakan dapat dilihat dari faktor range data penelitian yang sangat terpaut jauh, dapat mempengaruhi hasil data model serta nilai eror. Selain itu pengukuran tinggi muka air debit pengamatan masih menggunakan pengukuran yang sangat sederhana yaitu dengan papan bar, dengan kondisi di lapangan yaitu garis cat telah sedikit hilang, menjadikan data kurang akurat dalam pembacaan, sehingga mungkin terjadi kesalahan saat membaca dan mencatat tinggi muka air. Sehingga perlu lebih teliti dan selalu mengecek lokasi papan duga air. Selain itu perlu dilakukan cobacoba yang lebih banyak dengan merubah parameter sehingga dapat memperoleh hasil yang baik.

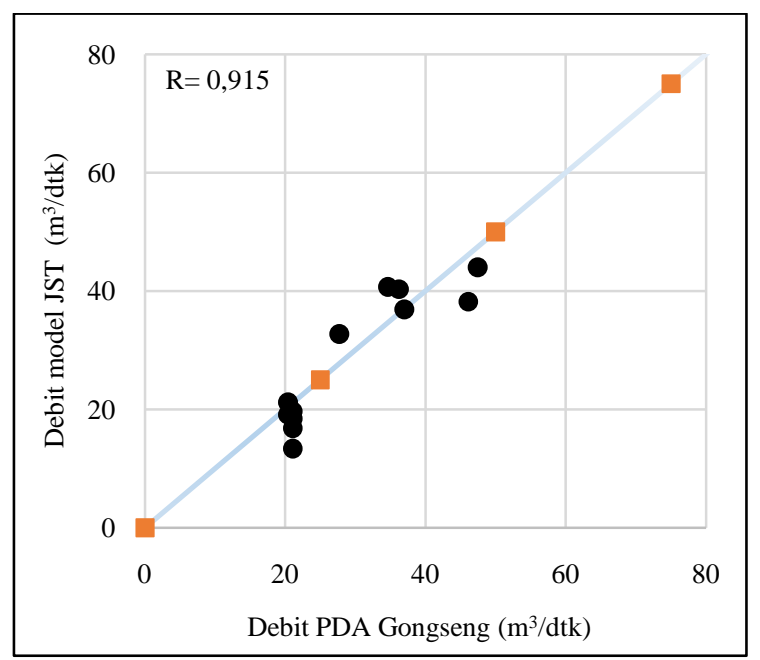

Gambar 10. Hubungan Debit Pos Duga Air dan Debit Model 9 Tahun Validasi Epoch 1000

Tabel 8. Uji Validasi Berdasarkan parameter NSE dan R

\begin{tabular}{ccccc}
\hline \multicolumn{5}{c}{ Data 6 Tahun } \\
\hline Epoch & NSE & Interpretasi & $\mathrm{R}$ & Tingkat Hubungan \\
\hline 1000 & 0,353 & Tidak Memenuhi & 0,354 & Rendah \\
\hline 2000 & 0,101 & Tidak Memenuhi & 0,416 & Sedang \\
\hline 3000 & 0,293 & Tidak Memenuhi & 0,292 & Rendah \\
\hline \multicolumn{5}{c}{ Data 5 Tahun } \\
\hline Epoch & NSE & Interpretasi & $\mathrm{R}$ & Tingkat Hubungan \\
\hline 1000 & 0,334 & Tidak Memenuhi & 0,693 & Kuat \\
\hline 3000 & 0,394 & Memenuhi & 0,693 & Kuat \\
\hline Epoch & 0,309 & Tidak Memenuhi & 0,666 & Kuat \\
\hline 1000 & NSE & Data 4 Tahun & Tingkat Hubungan \\
\hline
\end{tabular}




\begin{tabular}{|c|c|c|c|c|}
\hline 2000 & 0,497 & Memenuhi & 0,742 & Kuat \\
\hline 3000 & 0,300 & Tidak Memenuhi & 0,723 & Kuat \\
\hline \multicolumn{5}{|c|}{ Data 3 Tahun } \\
\hline Epoch & NSE & Interpretasi & $\mathrm{R}$ & Tingkat Hubungan \\
\hline 1000 & $-0,867$ & Tidak Memenuhi & 0,482 & Sedang \\
\hline 2000 & $-1,195$ & Tidak Memenuhi & 0,480 & Sedang \\
\hline 3000 & 0,139 & Tidak Memenuhi & 0,516 & Sedang \\
\hline \multicolumn{5}{|c|}{ Data 2 Tahun } \\
\hline Epoch & NSE & Interpretasi & $\mathrm{R}$ & Tingkat Hubungan \\
\hline 1000 & 0,130 & Tidak Memenuhi & 0,516 & Kuat \\
\hline 2000 & 0,276 & Tidak Memenuhi & 0,683 & Kuat \\
\hline 3000 & 0,320 & Tidak Memenuhi & 0,654 & Kuat \\
\hline \multicolumn{5}{|c|}{ Data 1 Tahun } \\
\hline Epoch & NSE & Interpretasi & $\mathrm{R}$ & Tingkat Hubungan \\
\hline 1000 & 0,794 & Baik & 0,915 & Sangat Kuat \\
\hline 2000 & 0,604 & Memenuhi & 0,830 & Sangat Kuat \\
\hline 3000 & 0,659 & Memenuhi & 0,858 & Sangat Kuat \\
\hline
\end{tabular}

\section{SIMPULAN}

Berdasarkan hasil dan pembahasan di atas, maka dapat disimpulkan bahwa hasil terbaik tahap Kalibrasi pada pembagian data 6 Tahun (2006-2011) menggunakan epoch 2000. Hasil terbaik tahap Verifikasi adalah pada pembagian data 1 tahun (2017) dengan epoch 1000. Sedangkan hasil terbaik tahap Validasi adalah pada pembagian data 1 tahun (2017) epoch 1000.

\section{DAFTAR PUSTAKA}

Ardana, Putu D.H., 2013, “Aplikasi Jaringan Syaraf Tiruan (Artificial Neural Networks) Dalam Kondisi Curah Hujan Limpasan Dengan Perbandingan Dua Algoritma Pelatihan (Studi Kasus: DAS Tukad Jogading)", Jurnal Konferemsi Nasional Teknik Sipil, Vol. 2: A 107- A 114

Asdak, Chay, 2007, Hidrologi dam Pengelolaan Daerah Aliran
Sungai, Yogyakarta, Gadjah Mada University Press Hadihardaja, I.K., Sutikno, S., 2005, Pemodelan Curah HujanLimpasan Menggunakan Artificial Neural Network (ANN) dengan Metode Back Propagation, Jurnal Teknik Sipil ITP, Vol 22 No. 4: 249-258

Hasim, Agus, 2008, Prakiraan Beban Listrik Kota Pontianak Dengan Jaringan Syaraf Tiruan (Artificial Neural Network), Tesis, Bogor, Institut Pertanian Bogor

Riad, S., Mania, J., Bouchaou, L., Najjar, Y., 2003, Rainfall-Runoff Model Using an Artificial Neural Network Approach.

Matematical and Computer Modelling. 40: 839-846

Soewarno, 2015, Analisis Data Hidrologi Menggunakan Metode Statistika dan Stokastik Seri Hidrologi, Yogyakarta, Graha Ilmu 
Widyastuti, Siska, Suhartanto, Ery, dan Dermawan, Very, 2016, Analisa Hujan Limpasan Menggunakan Model Artifical Neural Network (ANN) di Sub DAS Lesti, Jurnal Teknik Pengairan Universitas Brawijaya
Wahyuni, Sri, 2014, Perbandingan Metode MOCK dan Nreca untuk Pegalihragaman Hujan Ke Aliran, Jurnal Rekayasa, Vol 13 No. 2: 602-624 